\title{
6-7 Yaş İlkokul Dönemi Çocuklarının Spora İlişkin Görüşlerinin İncelenmesi*
}

\author{
Examining Views of Primary School Children Aged 6-7 on Sports
}

\section{ORİJINAL ARAȘTIRMA/ \\ ORIGINAL RESEARCH}

\author{
Murat SARIKABAK ${ }^{1 \dagger}$
}

Ali Asker RECEP ${ }^{2}$

Mert AYRANCI ${ }^{3}$

${ }^{1}$ Bartın Üniversitesi, Bartın. https://orcid.org/0000-0002-2778-295X

${ }^{2}$ Bartın Üniversitesi, Bartın https://orcid.org/0000-0002-3462-4626

${ }^{3}$ Bartın Üniversitesi, Bartın

https://orcid.org/0000-0003-4289-3049

\section{$\ddot{O} \mathbf{z}$}

Bireylerin erken yaşlarda spor ile tanışması, gelecek yaşamlarında spora ilişkin tutum ve davranışlarının önemli bir belirleyicisidir. İlköğretim dönemi ise çocukların gelişimlerinin desteklenmesi ve bazı alışkanlıkların kazanılmasında önemli bir zaman dilimidir. Yapılan araştırma da 6-7 yaş ilkokul çocuklarının spora ilişkin görüşlerini belirlemek amaçlanmıştır. Örneklem grubunu, Bartın ve İstanbul illerinde ilköğretim düzeyinde eğitim gören toplam 52 çocuk oluşturmaktadır. Nitel olarak yapılan çalışmada verilerin toplanmasında yarı yapılandırılmış görüşme formu kullanılmıştır. Katılımcılar ile gerçekleştirilen görüşmeler, katılımcıların kendilerini rahat ifade edebilecekleri ortamlar da uygulanmıştır. Veriler üzerinde içerik analizi yapılmıştır. Sonuç olarak; çocukların spor ve sporcu terimlerini tam olarak kavrayamadığı, sporun kimler tarafından nasıl ve nerede yapıldığına ilişkin sınırlı sayıda görüşe sahip oldukları, futbol, voleybol, atletizm ve basketbol gibi spor dallarını bildikleri belirlenmiştir. Sonuçlar literatür bilgileri 1şığında tartışılmış ve çocukların spora ilişkin bilgi ve aktivitelerinin arttırılması önerilmiştir.

Anahtar Kelimeler: İlköğretim, Spor, Bilgi Düzeyi

\section{Yayın Bilgisi}

Gönderi Tarihi: 09.11.2018

Kabul Tarihi: 26.12.2018

Online Yayın Tarihi: 31.12.2018

\begin{abstract}
Individuals getting involved in sports at an early age is an important determinant on their future attitude and behaviors regarding sports. Besides, primary education is an important period in supporting children's development and adopting certain habits. The present study aimed to identify primary school children's views on sports. The study group consisted of 52 schoolchildren who study at primary school in İstanbul and Bartın. The qualitative study used semi-structured interview form to collect data. The interviews were conducted in comfortable places where the participants could easily express themselves and content analysis was done on the data. The results revealed that children could not exactly grasp sports terms and that they had limited idea about how, by whom and where sports are done. On the other hand, the children knew about sports branches such as football, volleyball, athletics and basketball. The results were discussed in the light of literature and suggestions were made on increasing children's knowledge and activity of sports.
\end{abstract}

Key Words: Primary education, Sports, Knowledge level

\footnotetext{
*Bu çalışma, 15-18 Kasım 2018 tarihleri arasında Mardin'de düzenlenen III. Uluslararası Avrasya Spor, Eğitim ve Toplum Kongresinde sözel bildiri olarak sunulmuştur.

${ }^{\dagger}$ Sorumlu yazar: Murat Sarıkabak, msarikabak@bartin.edu.tr
} 


\section{GİRIŞ}

Spor kavramının insanlığın bir parçası olarak kabul edilmesine rağmen, bilim adamlarının ortak olarak belirlediği bir tanımı yoktur. Ancak insan gücüyle yapılan belirli aktiviteler spor ile bağdaştırılabilir. Spor; insanoğlunun var oluşundan beri onunla beraber olan, belirli kuralar içeren, rekabet ortamı olan, haz veren aktiviteler bütünlüğüdür (Zorba, 2015). Spor, ferde sabırlı ve enerjik olmayı, sosyal grup ve toplum ile bütünleşmeyi sağlarken, fert ile toplum arası ilişkileri daha ahlaki kılmaktadır. Spor sayesinde insanlar aynı amaçlara yönelmeye birlikte hareket etme duygusunu yaşamaya başlarlar. Spor, insanın toplumda yalnızlığı ve tek başına sorumsuzca hareketini önleme de bir unsurdur (Erkal, 1992). Toplumlar ferdin sıkıntılarını çözmeye ve çare aramaya mecbur hale gelmiştir. Çünkü insanların huzurlu, mutlu ve sağlıklı olması topluma da yansıyacaktır (Karahüseyinoğlu, 1998). Toplumda kaynaşma ve özdeşleşme konusunda spora önemli görevler düşer (Kazak, 2010).

Günümüzde hızla gelişen teknoloji, insan gücüne duyulan gereksinimi giderek azaltmış ve bunun sonucu olarak insanın doğal yapısına uymayan bir yaşam biçimi ortaya çıkmıştır. Böylece iş ve sosyal çevreden gelen baskılar, stres ve beraberinde gelen hastalıklar olumsuz durumların ortaya çıkmasına neden olmuştur. Spor, bu tehlikelere karşı dinamik, güncel yaşamın getirdiği streslerden uzak bir ortam yaratarak her yaştan bireye hem sağlıklı bir yaşam biçimi kazandırmakta hem de koruyucu tıbba yardımcı olmaktadır (Muratl1, 2013). Spor, fiziksel engelliler de dâhil olmak üzere bireyler arası fark gözetmeden toplumun değişik kesimlerinin ilgi alanına girmektedir (Amman, 1999). İnsan yaşamı ile birbirinden ayrılmaz bir bütün haline gelen spor, insanın tüm yaşamı boyunca sağlkklı, başarılı mutlu olmasında ve moral gücünü yüksek tutulmasında önemli bir rol oynamaktadır (Yalçınkaya, 1993).

İnsan, yaşamı boyunca sürekli bir gelişim ve değişim içindedir. İlköğretim dönemi, belki de bu gelişim sürecinin en önemli safhasını oluşturmaktadır. Çünkü bu süreç, çocukluktan erişkinliğe geçisin meydana geldiği ve bireyde sürekli ve süratli bir değişimin gözlenebildiği dönemdir (Şimşek, 2005). Okula başlama evresinden önceki dönemini sağlıklı geçiren çocukların, okul dönemi ve daha ileriki dönemlerdeki gelişimlerinin dayanıklı temeller üzerine kurulacağı bir gerçektir. Çocukların gelişiminde barınma, beslenme, sevilme, emniyet içinde olma gibi temel ihtiyaçlar dışında hareket etmeye ve oyun oynamaya da ihtiyacı vardır. Hareket becerisi büyüme 
ve gelişme de önemli rol oynamaktadır. Anne karnından başlayıp hayatın sonuna kadar devam eden insan hareketi, basit refleksif hareketlerden çıkarak karmaşık hareketlere kadar gelişim gösterir (Tepeli, 2010). Fiziksel becerilerde yeterliliklerini geliştirmeye yardımcı olunan çocuklar bu becerileri sadece okul yıllarında değil, tüm yaşamları boyunca kullanacaklardır (Stephen, 1999). Çocuklarda gelişme ve büyümeye etki eden genetik, beslenme, çocukluk hastalıkları, hatta kültür gibi çeşitli fonksiyonlar vardır. Bu nedenle fiziksel egzersizlerin gelişime ve büyümeye etkisini izole olarak göstermek oldukça zor olabilir. Çocuğun vücudunun iyi gelişebilmesi için en önemli nokta onun çok yönlü eğitilmesidir (Cox, 1998).

Çocuk doğumdan itibaren okul dönemine kadar öncelikli olarak aile üyeleriyle ilişki içerisindedir. Her şeyi onları taklit ederek öğrenir. Konuşma şekli, yemek yeme alışkanlığı, uyku düzeni, okuma isteğinden, müzik, sinema ve spora ilgi duymaya kadar tüm ilgileri aile içerisinde taklit yoluyla oluşur. Aile, sosyal dünyayı ve spor dünyasını görmeyi sağlayan ilk birimdir. Ailenin sosyalleşme üzerinde güçlü bir etkisi vardır. Aile, çocuğun nasıl spor yapacağını belirler. Bebek ile aile iletişimlerinin ilk dönemleri doğal olarak oyunsal tarzdadır. Bir çocuk, oyun deneyimlerini ilk olarak aile içinde görür. Aileler tarafından spora verilen pozitif değer spora ilgiliyi arttırır. Ailelerin sporla ilgili olması çocuğun spora katılımında, hatta sporun toplumun çoğunluğunca yapılmasında önemli bir etkendir (Aydoğan, Özyürek ve Akduman, 2015). Çocuklar oyun oynarken farklı sosyal ortamlarla karşılaşmakta ve bu ortamlarda iş birliği yapmayı, yardımlaşmayı, paylaşmayı ve karşılaştıkları sorunları uygun yollarla çözmeyi öğrenmektedirler. $\mathrm{Bu}$ durumun çocukların gelişimleri açısından önemli olduğu düşünülmektedir (Çelik ve Şahin, 2013).

Elde edilen veriler neticesinde özellikle aile faktörü bireylerin erken yaşlarından itibaren spor olgusu hakkında bilgiye sahip olmaları yolunda en önemli faktörler arasında yer almaktadır. Sporun bireyler üzerindeki fiziksel, psikolojik ve kişilik gelişimine katkısı göz önünde bulundurularak ve bireylerin benlik kavramının okula başlama evresinde (6-7 yaş) oluşmasıyla birlikte spor olgusu hakkında yeterli düzeyde bilgilendirilmeleri her açıdan pozitif yönde etki sağlayacaktır. Bu nedenle çalışmada hedeflenen amaç, 6-7 yaş ilkokul dönem çocuklarının spora ilişkin görüşlerinin incelenmesi olarak belirlenmiştir. Çalışma kapsamında çocukların; spor ve sporcu kavramlarının tanımı, spora ilişkin kimler tarafından neden ve nasıl yapıldığına bağlı, spor 
dalları konusundaki bilgileri ve tercihleri incelenmeye çalışılmış, bu amaçla araştırmanın hipotezleri aşağıdaki gibi oluşturulmuştur.

Hipotez 1. İlkokul dönemi 6-7 yaş çocukları spor ve sporcu ile ilgili temel kavramları bilmemektedir.

Hipotez 2. İlkokul dönemi 6-7 yaş çocukları spor uygulamalarını yeterince tanımamaktadır.

Hipotez 3. İlkokul dönemi 6-7 yaş çocuklarının spora özgü bilgi düzeyleri ailelerinin eğitim düzeyinden etkilenmektedir.

\section{YÖNTEM}

\section{Çalışma Grubu}

Araştırmanın çalışma grubunun belirlenmesinde, 'Kolay Ulaş1labilir Örneklem' tekniği kullanılmıştır. Bu örneklem yöntemi, araştırmaya hız ve pratiklik kazandırdığından, araştırmacı erişilmesi kolay olan durumu seçer (Yıldırım ve Şimşek, 2006). Yapılan araştırma için Bartın ve İstanbul illerindeki katılımcılara ulaşılmıştır. Bartın ili Ağdacı köyünde yer alan ve 2017-2018 eğitim öğretim yılında Ağdacı İlkokulu'na devam eden 6-7 yaş grubu toplamda 24 çocuk katılımcı çalışmaya dâhil edilirken, İstanbul ilinde Arnavutköy ilçesinde yer alan, 2017-2018 eğitim öğretim yılında Hasan Tahsin İlkokulu'na öğrenimine devam eden 6-7 yaş grubu 28 çocuk katılımcı ya ulaşılmış, toplam da 52 çocuk katılımcı ile görüşülmüştür

\section{Veri Toplama Aracı}

Araştırmada veri toplama aracı olarak yarı yapılandırılmış görüşme formu kullanılmıştır. Karşılaştırmalı sonuçlar elde etmek amacıyla, tercih edilen yarı yapılandırılmış görüşme formu, araştırma soruları ve çocukların gelişim düzeyleri doğrultusunda geliştirilmiştir. Araştırmacılar tarafından geliştirilen görüşme sorularının hazırlanmasında; soruların kolaylıkla anlaşılması ve tek bir boyutu ele almasına dikkat edilmiştir. Hazırlanan görüşme formu amaca uygunluk ve içerik geçerliliğini sağlamak amacıyla uzman görüşüne sunulmuştur. Alan uzmanlarından gelen görüş ve öneriler doğrultusunda görüşme formuna son şekli verilerek on çocuk ile bir ön uygulama gerçekleştirilmiştir.

Görüşme formunda yer alan sorular aşağıda belirtilmiştir: 
Sarıkabak, M., Recep, A.A. ve Ayrancı, M. (2018). 6-7 Yaş ilkokul dönemi çocuklarının spora ilişkin görüşlerinin incelenmesi. CBÜ Beden Ĕgitimi ve Spor Bilimleri Dergisi, 13(2), 405-417.

- Spor nedir?, Sporcu nedir?, Tanıdığın sporcu var mı? (NE?)

- Kimler spor yapar?, Sen spor yapıyor musun?, Evde/Ailenden kim spor yapıyor? (KIM?)

- Spor niçin yapılır?, Yapılmazsa ne olur? (NİÇíN?)

- Spor nerede yapılır? Spor başka nerelerde yapılabilir? (NEREDE?)

- Spor nasıl yapılır?, Spor yaparken neler kullanılır? (NASIL?)

- Hangi spor dallarını biliyorsun?, Sen hangi sporu yapmak istersin? (HANGí?)

\section{Verilerin Analizi}

Veriler toplanırken yapılan görüşmeler, sınıf dışında ve katılımcıların kendini rahat ifade edebileceği bir ortamda gerçeklemiştir. Yapılan görüşmede katılımcıları etkileyebileceği etkenlerden uzak bırakarak not alma tekniği kullanılmıştır. Bu şekilde her görüşme yaklaşık 15 dakika sürmüştür.

\section{BULGULAR}

Araştırmanın bu bölümünde, ilköğretim dönemi çocuklarının görüşleri belirlenen temalar çerçevesinde sunulmuştur. Çalışma grubunda yer alan çocukların görüşleri gizlilik esasına dayanılarak, isimleri verilmeden kodlanarak aktarılmıştır. Buna göre katılımcılar " $K$ " olarak kodlanmış, her katılımcıya kodunun yanında "K1, K2" şeklinde bir numara verilmiş̧ir.

Tablo 1. Çocukların Spor nedir?, Sporcu nedir?, Tanıdığın sporcu var mı? (Ne?) Sorularına Yönelik Görüşleri

\begin{tabular}{lcc}
\hline Spor Nedir & Bartın & İstanbul \\
& N & N \\
\hline Futbol Oynamak & 7 & 5 \\
Koşmak & 5 & 6 \\
Sağlıklı Olmak & 3 & 2 \\
Zayıflamak & 2 & 2 \\
Yüzmek & - & 1 \\
Karate & 1 & - \\
Şınav & 1 & - \\
Bilmiyorum & 5 & 12 \\
Toplam & 24 & 28 \\
\hline
\end{tabular}

Bartın ilinde çocukların "spor nedir?" sorusuna verdikleri cevaplar incelendiğinde en yüksek oranda futbol oynamak cevabının verildiği görülmektedir. Bu cevabı takiben "koşmak" ve "bilmiyorum" cevapları 5'er çocuk tarafından cevap olarak verilmiştir. "sporcu nedir?" sorusu 
Sarıkabak, M., Recep, A.A. ve Ayrancı, M. (2018). 6-7 Yaş ilkokul dönemi çocuklarının spora ilişkin görüşlerinin incelenmesi. CBÜ Beden Ĕ̈itimi ve Spor Bilimleri Dergisi, 13(2), 405-417.

yöneltildiğinde ağırlıklı olarak 9 çocuk tarafından verilen cevap “spor yapan kişi/adam” olmasına rağmen 7 çocuk da bilmiyorum cevabını vermiştir.K9 ise "karate" yapan cevabını vermiştir. “Tanıdığın sporcu var mı?” sorusuna 2'şer kez “babam" ve “arkadaşım”, cevapları alınırken K15 “abim" cevabını vermiştir. Aynı soruya geriye kalan 19 katılımcı "tanımıyorum” cevabını vermiştir.

İstanbul ilinde ise çocukların "spor nedir?" sorusuna verdikleri cevaplar incelendiğinde en yüksek oranda "bilmiyorum”' cevabının verildiği görülmektedir. Bu cevabı takiben 6 çocuğun da “koşmak" cevabını verdiği görülmüştür. "Sporcu nedir?” sorusu yöneltildiğinde ise ağırlıklı olarak 18 çocuk tarafindan verilen cevap "bilmiyorum" olmasına rağmen 7 çocuk ise "spor yapan” kişi cevabını vermiştir. K16 ise "yetenekli” olan kişi cevabını vermiştir. "Tanıdığın sporcu var mı?” sorusu sorulduğunda ise ağırlık olarak çocukların “yok/bilmiyorum” cevaplarını verdikleri görülmektedir. Bu cevabı takiben 12 çocuğun ise futbol oynayan kişilerin isimlerini verdikleri görülmüştür. K28 ise diğer çocuklardan ayrı olarak "Naim Süleymanoğlu” demiştir.

Tablo 2. Çocukların Kimler spor yapar?, Sen spor yapıyor musun?, Evinizde başka kim spor yapıyor? (Kim?) sorularına yönelik görüşleri

\begin{tabular}{lcc}
\hline Kimler Spor Yapar? & Bartın & İstanbul \\
& $\mathrm{N}$ & $\mathrm{N}$ \\
\hline Sporcular & 8 & 12 \\
Erkekler & 11 & 10 \\
Insanlar & 1 & 1 \\
Bilmiyorum & 4 & 5 \\
Toplam & 24 & 28 \\
\hline
\end{tabular}

Bartın ilinde tablo 2. incelendiğinde 8 çocuğun çoğunlukta “'sporcular' cevabını verdiği görülürken 11 çocuk“"erkekler’, 1 çocuk “insanlar', 4 çocuk ise “bilmiyorum”, cevabını vermiştir. "Erkekler', cevabını veren 5 çocuğun cinsiyeti kızdır.

“Sen spor yapıyor musun?” sorusuna 7 çocuk “'hayır”' cevabını verirken diğerleri “"evet”, cevabını vermiştir. “'Evet”' cevabını veren K2 “bisiklet sürüyorum” K11 “'havuzda yüzüyorum”, K9 “"karate'” yapıyorum cevaplarını vermiştir. "Evinizde başka kim spor yapıyor” sorusuna 8 çocuk "babam", 6 çocuk "annem”, cevabını verirken 7 çocuk ise "kimse spor yapmıyor”' cevabını vermiştir. K4 ve K21 katılımcıları “ağabeyim”, cevabını, K18 “ablam”’ cevabını vermiştir. 
Sarıkabak, M., Recep, A.A. ve Ayrancı, M. (2018). 6-7 Yaş ilkokul dönemi çocuklarının spora ilişkin görüşlerinin incelenmesi. CBÜ Beden Eğitimi ve Spor Bilimleri Dergisi, 13(2), 405-417.

İstanbul ilinde ki katılımcılara ait tablo 2. incelendiğinde 12 çocuğun çoğunlukta “sporcular” cevabını verdiği görülürken 10 çocuk "erkekler", 1 çocuk “insanlar" cevabını vermiştir. 5 çocuğun da "bilmiyorum” cevabını verdikleri görülmüştür. Erkekler cevabını veren 3 çocuğun cinsiyeti kızdır.

"Sen spor yapıyor musun?" sorusuna 8 çocuk "hayır" cevabını verirken diğerleri "evet" cevabını vermiştir. "Evet”" cevabını veren K28 “ağırlık kaldırıyorum” demiştir. K1 ise "bazen”" cevabını vermiştir. "Evinizde başka kim spor yapıyor" sorusuna 6 çocuk "ağabeyim", 3 çocuk “amcam”, 4 çocuk “'babam” cevabını verirken K6 “annem” K1 ve K5 ise “ablam” cevabını vermiştir. Diğer çocuklar ise "yok/bilmiyorum” cevabını vermiştir.

Tablo 3. Çocukların Spor niçin yapılır?, Yapılmazsa ne olur?, (Niçin?) sorularına yönelik görüşleri

\begin{tabular}{lcc}
\hline Spor Niçin Yapılır? & Bartın & İstanbul \\
& $\mathrm{N}$ & $\mathrm{N}$ \\
\hline Sağlıklı Olmak İçin & 11 & 11 \\
Güçlü Olmak İçin & 2 & 5 \\
Zayıflamak İçin & 7 & 3 \\
Büyümek İçin & 3 & 3 \\
Bilmiyorum & 1 & 6 \\
Toplam & 24 & 28 \\
\hline Yapılmazsa Ne Olur? & Bartın & İstanbul \\
& $\mathrm{N}$ & $\mathrm{N}$ \\
\hline Sağlıklı Olamayız & 11 & 11 \\
Güçlü Olamayız & 2 & 5 \\
Zayıflayamayız & 7 & 3 \\
Büyüyemeyiz & 3 & 3 \\
Bilmiyorum & 1 & 6 \\
Toplam & 24 & 28 \\
\hline
\end{tabular}

Bartın ilinde tablo 3'e göre "Spor Niçin Yapılır?" sorusuna ağırlıklı olarak 11 çocuk tarafından "sağlık için”" cevabı verilirken, 7 çocuk "zayıflamak için”, 3 çocuk "büyümek için”, 2 çocuk "güçlü olmak" için cevabını vermiştir. K7 "bilmiyorum” cevabını vermiştir. "Yapılmazsa ne olur?” sorusuna ise 11 çocuk "sağlıklı olamayız” cevabını verirken, 7 çocuk “zayıflayamayız”, 3 çocuk “büyüyemeyiz”, 2 çocuk “güçsüz kalıız”’ cevabını verirken K7 ise "bilmiyorum" cevabını vermiş̧ir.

İstanbul ilinde ise tablo 3'e göre "Spor Niçin Yapılır?" sorusuna ağırlıklı olarak 11 çocuk “sağlıklı olmak için” cevabını verirken, 5 çocuk “güçlü olmak için”, 3 çocuk “büyümek için”, 3 çocuk ise "zayıflamak için" cevabını, 6 çocuk ise "bilmiyorum" cevabını vermiştir. 
Sarıkabak, M., Recep, A.A. ve Ayrancı, M. (2018). 6-7 Yaş ilkokul dönemi çocuklarının spora ilişkin görüşlerinin incelenmesi. CBÜ Beden Ĕgitimi ve Spor Bilimleri Dergisi, 13(2), 405-417.

"Yapılmazsa ne olur?" sorusuna ise 11 çocuk "sağlıklı olamayız” cevabını verirken, 5 çocuk “güçlü olamayız”, 3 çocuk “büyüyemeyiz”, 3 çocuk “zayıflayamayız” cevabını, 6 çocuk ise "bilmiyorum" cevabını vermiştir.

Tablo 4. Çocukların spor nerede yapılır?, Spor başka nerelerde yapılabilir? (Nerede?) sorularına yönelik görüşleri

\begin{tabular}{lcc}
\hline $\begin{array}{l}\text { Spor nerede yapılır/ } \\
\text { başka nerelerde yapılabilir? }\end{array}$ & Bartın & İstanbul \\
\hline Spor Salonu & $\mathrm{N}$ & $\mathrm{N}$ \\
Futbol Sahası & 12 & - \\
Dışarıda & 11 & 10 \\
Evde & - & 11 \\
Bilmiyorum & - & 1 \\
Toplam & 1 & 6 \\
\hline
\end{tabular}

Bartın ilinde çocuklara yöneltilen "Spor nerede yapıllı?" ve "Spor başka nerelerde yapılabilir?" sorularına ağırlıklı olarak "spor salonunda(12)" ve "futbol sahasında(11)" cevapları alınmakla birlikte K7 katılımcısından “bilmiyorum” cevabı alınmıştır.

İstanbul ilinde ise çocuklara yöneltilen "Spor nerede yapılır?" ve "Spor başka nerelerde yapılabilir?" sorularına ağılıklı olarak "dışarıda(11)" ve "futbol sahasında(10)" cevapları alınmakla birlikte K14 “evde” cevabını verirken 6 çocuk ise "bilmiyorum” cevabını vermiştir.

Tablo 5. Çocukların Spor nasıl yapılır?, Spor yaparken neler kullanılır? sorularına yönelik görüşleri

\begin{tabular}{lcc}
\hline Spor Nasıl Yapılır? & Bartın & İstanbul \\
& $\mathrm{N}$ & $\mathrm{N}$ \\
\hline Koşarak & 12 & 7 \\
Futbol Oynayarak & 5 & 3 \\
Bisiklet Sürerek & 3 & - \\
Ziplayarak & 2 & - \\
Şınav Çekerek & - & 4 \\
Yüzerek & 1 & - \\
Bilmiyorum & 1 & 14 \\
Toplam & 24 & 28 \\
\hline Spor Yaparken & Bartın & İstanbul \\
Neler Kullanılır? & $\mathrm{N}$ & $\mathrm{N}$ \\
\hline Aletle & 9 & 3 \\
Futbol Topu & 5 & 3 \\
Basketbol Topu & 3 & 2 \\
Vücudumuzla & 4 & - \\
Koşu Bandı & - & 1 \\
Ağırlıklar İle & - & 4 \\
Bilmiyorum & 3 & 15 \\
Toplam & 24 & 28 \\
\hline
\end{tabular}


Sarıkabak, M., Recep, A.A. ve Ayrancı, M. (2018). 6-7 Yaş ilkokul dönemi çocuklarının spora ilişkin görüşlerinin incelenmesi. CBÜ Beden Ĕgitimi ve Spor Bilimleri Dergisi, 13(2), 405-417.

Bartın ilinde çocuklara "Hangi sporu yapmak istersin?” sorusuna karşılık olarak çocukların 10'u 'futbol"' cevabını vermiştir. Geriye kalan çocukların 8'i “"voleybol'” cevabını verirken 4'ü "basketbol" yapmak istediğini belirtirken, "karate" ve "tenis" yapmak isteyenlerin 1'er kişi oldukları görülmüştür. Çocuklara "Hangi spor dallarını biliyorsun?" sorusu yöneltildiğinde ağırlıklı olarak "futbol(10)" cevabı verilmiştir. Haricen "basketbol(4)", “voleybol(8)", “tenis(1)" ve "karate(1)" cevapları soruya karşılık olarak alınmıştır.

İstanbul ilinde ise "Hangi sporu yapmak istersin?" sorusu yöneltildiğinde ağıllıklı olarak 10 çocuk tarafından "futbol" cevabı verilirken 7 çocuk ise "atletizm" cevabını vermiştir. Haricen “'basketbol(1)”, “halter(2)”, “yüzme(1)”, “'boks(2)”, “hentbol(1)” cevabı görülürken 3 çocuk ise "bilmiyorum" cevabını vermiştir. Bir diğer soru "Hangi spor dallarını biliyorsun?" sorusuna verilen cevaplar ise ağırlıklı olarak "futbol(10)" cevabı verilirken onu takiben "atletizm(7)",


alınırken 3 çocuk ise "bilmiyorum" cevabını vermiştir.

Tablo 6. Çocukların Annenizin ve Babanızın Mesleği Nedir? sorusuna yönelik görüşleri

\begin{tabular}{lcc}
\hline Annenizin Mesleği & Bartın & İstanbul \\
& $\mathrm{N}$ & $\mathrm{N}$ \\
\hline Ev Hanımı & 13 & 16 \\
İşçi & 3 & 8 \\
Memur & 3 & 2 \\
Öğretmen & 5 & 2 \\
Toplam & 24 & 28 \\
\hline Babanızın Mesleği & Bartın & İstanbul \\
& $\mathrm{N}$ & $\mathrm{N}$ \\
\hline İş̧i & 9 & 20 \\
Akademisyen & 7 & - \\
Öğretmen & 6 & 2 \\
Memur & - & 4 \\
Veteriner & 1 & - \\
Mühendis & 1 & - \\
Doktor & - & 2 \\
Toplam & 24 & 28 \\
\hline
\end{tabular}

Bartın ilinde, çocuklara “Annenizin ve Babanızın Mesleği Nedir?” yöneltildiğinde anne mesleği olarak 13 çocuk “ev hanımı”, baba mesleği olarak 9 çocuk "işçi”' cevaplarını verirken diğer cevaplar ise şöyle; “işçi(3)”, “memur(3)”, “öğretmen(5)” anne mesleği. “Akademisyen(7)", “öğretmen(6)", “veteriner(1)", “mühendis(1)” baba mesleği cevaplarını vermiştir. 
Sarıkabak, M., Recep, A.A. ve Ayrancı, M. (2018). 6-7 Yaş ilkokul dönemi çocuklarının spora ilişkin görüşlerinin incelenmesi. CBÜ Beden Ĕgitimi ve Spor Bilimleri Dergisi, 13(2), 405-417.

\section{TARTIŞMA VE SONUÇ}

Gelişen teknoloji beraberinde sedanter yaşamı da getirmiştir. Giderek artan hareketsiz yaşamın beraberinde getirdiği sağlık sorunları artık koruyucu hekimliğin vazgeçilmez ve önemli konularından biri olmuştur. Fiziksel aktivitenin artırılmasına yönelik yapılan çalışmaların önemi ve sayısı her geçen gün artmaktadır. Kalıcı davranışlara ulaşmada erken yaşın etkisinin büyük olması da artık kabul edilen bir geçek olarak görünmektedir. Bu nedenle çalışmada hedeflenen amaç, kalıcı davranışlara ulaşma döneminin başında olan, 6-7 yaş ilkokul dönem çocuklarının, spora ilişkin görüşlerinin incelenmesi olarak belirlenmiştir.

Katılımcıların aile eğitim düzeylerine göre, verdikleri cevaplar incelendiğinde, eğitim düzeyi yüksek olan ailelerin çocuklarında, daha kapsamlı cevaplara ulaşı1ııştır. "Sporcu Nedir?" sorusunda verilen cevaplar arasında "bilmiyorum" cevabının ağırlıklı olduğu görülmüşstür. Spor ve sporculuk kavramının çocuklara doğru aktarılmadığı ve bu konuda eksiklikler olduğu düşünülmektedir. Anne ve babalar, çocukların beden eğitimi ve spor aktivitelerine katılımları açısından örnek oluşturacak şekilde spor yapmalı veya kendileri de fiziksel olarak etkinliklerde bulunarak çocuklara örnek olmalıdırlar. Çocukların spora katılımları desteklenmeli, ödüllendirilmeli ve ilgi gösterilmelidir (Güven ve Öncü, 2006). Aileyi model alan ve taklit eden varlıklar olarak, aileler büyük oranda çocuklar için örnek teşkil etmektedir.

“Kimler Spor Yapar?” sorusuna bazı bayan katılımcılar erkekler diyerek cevap vermiştir. Gürbüz ve Tank (2006) tarafından Ankara Üniversitesi’nde okuyan 769 öğrenci üzerinde yapılan bir araştırmada cinsiyet ve spor yapma oranı arasında anlamlı bir ilişki bulunmuştur. Buna göre erkekler daha fazla spor yapmaktadır (Yüksel, 2014). Toplumda erkeklerin bu kadar baskın olması nedeniyle bazı kız öğrenciler "Kimler Spor Yapar?” sorusuna erkekler diyerek cevap vermiş olabilir. Bu tarz olumsuz baskı ve düşünceler sonucunda spora katılım oranı kadınlara göre erkeklerde sayısal olarak bir üstünlük gösteriyor olabilir. Bu algının çalışmamızda, bayan katılımcıların erkeklerin spor yaptığına dair verdikleri cevaplar üzerinde etkili olduğu düşünülebilir.

Çocukları spor ve egzersiz ile ilgili olarak, eğlence ve oyun boyutunu da dahil ettiğimiz motive edici çalışmalarla fiziksel aktivitelere çekmeliyiz. Çocukları daha geniş perspektifte bilgilendirmek, çocukların bakış açısını genişletecektir. Ülkemizde sosyo-ekonomik imkânlar, tabakalar, bölgeler ve kır-kent arasındaki dağılım eşit veya adil olamadığı için, ailenin maddi 
sorunları da buna eklenince, çocukların öğrenim yaşamı yarıda kalabilmektedir. Bunun sonucu olarak da eğitim seviyesi düşmekte, spor da gelişememektedir (Kotan, Hergüner ve Yaman, 2009). Araştırma genelinde elde edilen veriler neticesinde, eğitim düzeyi yüksek olan ailelerin, eğitim düzeyi düşük olan ailelere oranla, çocuklarına spora yönelik daha fazla eğitim verdiği görülmektedir.

"Spor Yapmazsak Ne Olur?" sorusuna verilen cevaplar incelendiğinde çocukların sağlık ve futbol dışında bir seçenek oluşturamadığı gözlemlenmiştir. Bunun sebebi ise spor ile ilgili bilgilerin eksikliği olabilir. Bir diğer eksiklik olarak da çocukların hareket alanlarının daralmaya başlaması ve spor uygulama alanlarının büyük şehirlerdeki eksikliğinin yüksek oluşu olarak görülebilir. Bu düşünceyi destekleri nitelikteki bir çalışmayı ise Sadık (2014) yapmış ve şehir merkezlerinde çocukların oyun ve yaşam alanlarının daraldığını belirtmiştir. "Spor Nerede Yapılır?" sorusundan elde edinilen bilgiler genel olarak aynı olup, ailelerden uzak mekânların spor için algılanan yerler olduğu görülmüsstür. Spor aktivitelerini çeşitlendirmek ve mekân değiş̧iklileri oluşturmak, bu soruna çözüm olarak düşünülmüştür. Çeşitli aktiviteleri uygulamanın, yalnızca mekân algısı olarak değil, egzersiz çeşitliliği de sağlayacağı için, "Spor Nasıl Yapılır?” sorusuna verilecek cevaplarda da olumlu sonuçları arttıracağı düşünülmektedir.

Çocukların sorulan birçok soruya verdikleri cevap "futbol" kavramı ile başlamaktadır. Toplum içinde çoğunluğun, büyük bir kesimin tercih ettiği, ilgi duyduğu, içinde yaşattığı olgular toplamı olarak tanımlanabilen popüler kültür, varlığını kitle iletişim araçlarına borçludur. Popüler kültür kapsamına giren bir uğraş ve eğlence alanı da futboldur. Futbol da popüler kültürün özelliklerinden yararlanarak kendi meşruiyetini kazanmaktadır (Şentürk, 2007). Buna bağlı olarak özellikle erkek çocukların ilgilerinin yoğunlaşıtı̆ı bu spor, elde edilen veriler neticesinde, rakamsal olarak üstünlük göstermektedir. Gelişmiş ülkelerde uygulanan farklı branşların popülaritesini arttırma çabası, ülkemizde de uygulanarak, bu soruya verilecek yanıtların çeşitliliğini arttırabilir.

Okula başlama dönemi olan 6-7 yaş grubu çocuklarda, spora ilişkin görüşlerin incelenmesi amacıyla gerçekleştirilen araştırma sonucunda, sporun genel anlamda futbol ve sağlıklı yaşam amacı olarak görüldüğü gözlemlenmiştir. İlkokul dönemi çocukları, sporcu kavramı konusundaki eksiklikleri nedeni ile çoğu sporcuyu tanımadıklarını cevap olarak vermiş̧lerdir. Çevrelerinde spor yapan ve yapmayanlardan etkilenmeleri ile ilgili soruya verdikleri cevaplarda, bilgilerinin olmadığı ya da daha çok göz önünde bulunan, herkes tarafından daha çok bilinen, etraftan daha 
Sarıkabak, M., Recep, A.A. ve Ayrancı, M. (2018). 6-7 Yaş ilkokul dönemi çocuklarının spora ilişkin görüşlerinin incelenmesi. CBÜ Beden Ĕ̈itimi ve Spor Bilimleri Dergisi, 13(2), 405-417.

fazla duydukları sporları (futbol, basketbol vb.) örnek olarak verdikleri tespit edilmiştir. Ülkemizde ve dünya da popülerliği kanıtlanmış olan futbol branşı, bilinen ve yapılmak istenilen sporlar arasında en çok en çok tercih edilen cevap olarak karşımıza çıkmıştır. Cinsiyet faktörü de verilen cevaplar üzerinde ve sporla ilgili tercihler açısından önemli bir belirleyici olarak görülmektedir. Ailelerin eğitim düzeyleri ve mesleklerinin, çocukların verdikleri cevapları etkilediği düşünülmüştür. Ailelerinde eğitimci (akademisyen, öğretmen vb.) bireylerin bulunduğu çocuklar daha bilinçli cevaplar verirken, maddi gelirleri daha düşük olduğu düşünülen meslek gruplarında istihdam edilen ailelerin çocukları, spor ile ilgili daha sade cevaplar vermiştir.

Çocuk gelişiminin, anne karnında duyusal, duygusal ve fiziksel gelişimine başladığı ve bu özelliklerin annenin yaşantılarından etkilendiği bilinmektedir. Ruhsal, sosyal ve fiziki gelişim için çocuklara ve annelere, anne karnında başlayan ve ilk çocukluk yıllarında artarak devam eden spor aktiviteleri ve yeteneklerine uygun spor çeşitliliği sunulmalıdır. Çocuk bu aktivitelere dair spor ve sporcu kavramları konusunda bilinçlendirilip spora istekli hale getirilebilir. Okullarda spora verilen değer artmalı ve küçük yaşlarda sporun çocuklar için alışkanlığa dönüşmesi sağlanmalıdır. Bu konuda aileler ve eğitimcilerin hizmet içi eğitim ve çeşitli çalıştaylar yoluyla bilgilenmelerinin sağlanması büyük önem arz edebilir. İlkokullarda uygulanan beden eğitimi ve spor dersi sürelerinin arttırılması, gelişime olan katkısı açısından önerilebilir.

\section{KAYNAKLAR}

Amman, M.T. (1999). Modernlik ve modernleşme ekseninde günümüz sporuma makrasosyolojik bir bakış. Spor Araştırmaları Dergisi, 3(1), 47-57.

Aydoğan, Y., Özyürek, A. ve Akduman, G. (2015). Okul öncesi dönem çocuklarının spora ilişkin görüşlerinin incelenmesi. International Journal of Science Culture and Sport, 3(4), 597-569.

Cox, R.H. (1998). Sport Psychology: Concept and applications. p.30, 263-265, Boston: Mcgraw-Hill.

Çelik, A. ve Şahin, M. (2013). Spor ve çocuk gelişimi. The Journal of Academic Social Science Studies JASSS-International Journal of Social Science, 6(1), 467-468.

Erkal, M. (1992). Sosyolojik açıdan spor. İstanbul: Türk Dünyası Araştırmalar Vakfı, Kutsun Matbaa ve Reklamcılık Merkezi, 8690.

Gürbüz, S. ve Tank, F. (2006). Ankara üniversite öğrencilerinin, ankara üniversitesi tarafindan sunulan spor olanaklarından yararlanma düzeyi, 9. Uluslararası Spor Bilimleri Kongresi bildiri kitabı içinde (ss. 971-973) Muğla Üniversitesi.

Güven, Ö. ve Öncü, E. (2006). Beden eğitimi ve spor katılımda aile faktörü. Aile ve Toplum, Eğitim ve Araştırma Dergisi, 3(10), 82-88.

Karahüseyinoğlu, M.F. (1998). Elazığ kamuoyunun spora karşı ilgi ve tutumları. Yayımlanmamış yüksek lisans tezi. Fırat Üniversitesi, Elazığ.

Kazak, H. (2010). Illköğretim öğrencilerinin spora başlamasında sosyal faktörlerin rolü: Muş İli örneği. Yüksek lisans tezi. Sakarya Üniversitesi, Sakarya. 
Sarıkabak, M., Recep, A.A. ve Ayrancı, M. (2018). 6-7 Yaş ilkokul dönemi çocuklarının spora ilişkin görüşlerinin incelenmesi. CBÜ Beden Ĕ̈itimi ve Spor Bilimleri Dergisi, 13(2), 405-417.

Kotan, Ç., Hergüner, H. ve Yaman, Ç. (2009). İlköğretim okullarında okuyan sporcu öğrencilerin spor yapmalarında okul ve aile faktörünün etkisi: Sakarya İli örneği. Niğde Üniversitesi Beden Ĕ̆itimi ve Spor Bilimleri Dergisi, 3(1), 49-58.

Muratl1, S. (2013). Çocuk ve spor. Ankara: Nobel Akademik Yayıncılık

Sadık, F. (2014). Çocuk ve çevre sorunları: çocukların algıladıkları çevre sorunlarıyla ilgili görüşlerin incelenmesi. Akademik Sosyal Araştırmalar Dergisi, 2(8), 114-133.

Stephen, W.S. (1999). Physical education methods for classroom teacher, Med Wirgia Technology Unıversity, Human Kinetics Publishers, Champing, 1-6.

Şentürk, Ü. (2007). Popüler bir kültür örneği olarak futbol. C.Ü. Sosyal Bilimler Dergisi, 31(1), 39.

Şimşek, Y. K. (2005). Çocukların spora yönlendirilmesinde ailenin görüşlerinin değerlendirilmesi: Eskişehir İli örneği. Yüksek lisans tezi. Anadolu Üniversitesi, Eskişehir.

Tepeli, K. (2010). Motor (hareket) gelişim, erken çocukluk döneminde gelişim (2.baskı), Ankara: Maya Akademi.

Yalçınkaya, M., Saracaloğlu, A. ve Varol R. (1993). Üniversite öğrencilerinin spora ilișkin görüşleri ve beklentileri. Spor Bilimleri Dergisi, 4(2), 12-26.

Yıldırım, A., Şimşek, H. (2006). Sosyal Bilimlerde Nitel Araştırma Yöntemleri. Ankara: Seçkin Yayınevi.

Yüksel, M. (2014). Cinsiyet ve spor. Tarih Okulu Dergisi, Sayı:19, 663-684.

Zorba, E. (2015). Herkes için yaşam boyu spor. Ankara: Fırat Matbaacılık, 5. Bask1, 16-41. 